\title{
PENGINTEGRASIAN PIDANA KERJA SOSIAL DALAM SISTEM HUKUM NASIONAL
}

Wafda Vivid Izziyana, Arham Anom Besari

Fakultas Hukum, Universitas Muhammadiyah Ponorogo

Jl. Budi Utomo No.10, Ronowijayan, Siman, Kabupaten Ponorogo, Jawa Timur 63471

Telp/Fax: (0352) 481124, e-mail:wafda.vivid@yahoo.co.id

\begin{abstract}
Abstrak
Pemidanaan menjadi problem dalam sistem hukum Indonesia. Tujuan dari pemidanaan adalah bentuk perlindungan bagi segenap tumpah darah Indonesia sebagaimana tertuang dalam pembukaan UUD 1945, pemidanaan harus mempertimbangkan humanism. Banyak yang memepertanyakan keefektifan pidana penjara terutama dari akibat negatif. kondisi lapas menimbulkan kritik, Lapas sering dijadikan sebagai sekolah bagi para penjahat yang melahirkan penjahat professional, Pemidanaan yang bersifat modern, vonis tidak harus penjara. jika seorang masuk penjara, maka akan menjadi beban negara, sekaligus menyediakan fasilitas yang jumlah nya sangat besar. Sanksi kerja sosial jauh lebih bermanfaat dari pada pidana penjara. peraturan hukum positif yang akan datang (ius constitutum) terutama peraturan mengenai pemidanaan kerja sosial yang dapat dirumuskan secara lebih baik dengan tujuan utama melindungi masyarakat dan merehabilitasi pelaku kejahatan. Perlu merumuskan secara tepat tentang pidana kerja sosial sehingga dapat berlaku dengan efektif dan mencapai tujuannya secara tepat.
\end{abstract}

Kata kunci : pidana, kerja sosial, sistem hukum

\section{A. Pendahuluan}

Hukum merupakan salah satu unsur yang tidak bisa dipisahkan dari masyarakat, hubungan antara hukum dan masyarakat adalah hubungan yang timbal balik $^{1}$ hukum akan berkembang seiring dengan perkembangan masyarakan, sehingga jika dalam pejalanan waktu masyarakat akan berkembang, otomatis membutuhkan perbaruan hukum yang

\footnotetext{
${ }^{1}$ Syahrani Ridwan, (2004), Rangkuman intisari ilmu hukum edisi revisi, Bandung: Citra Aditya Bakti,.hlm 27.
}

mampu mengimbangi perkembangan masyarakat. Satu dari aspek hukum diantaranya adalah tentang pemidanaan, yang mana prosesnya yang dikenal sebagai hukum pidana. Pidana sendiri berasal dari kata belanda yaitu straf atau lebih dikenal juga sebagai hukuman atau sanksi, lebih tepat diartikan sebagai penderitaan yang ditimpakan oleh Negara, oleh kekuasaan judikatif kepada seseorang atau beberapa orang sebagai sebuah konsekuensi hukum dikarenakan 
telah melakukan pelanggaran hukum, tindakan melanggar hukum ini dikenal sebagai tindak pidana ${ }^{2}$. Andi Hamzah berpendapat pidana atau Pemidanaan disebut sebagai penjatuhan pidana atau penghukuman. ${ }^{3}$

Fenomena dalam sistem pemidanaan menjadi problem dalam sistem hukum Indonesia. Tujuan dari pemidanaan yang diberlakukan adalah bentuk perlindungan bagi segenap tumpah darah Indonesia sebagaimana tertuang dalam pembukaan UndangUndang Dasar 1945 yaitu "Melindungi segenap bangsa Indonesia dan untuk memajukan kesejahteraan umum”. Inilah landasan umum dan tujuan dari penerapan dan penegakan hukum di Indonesia.

Tujuan dari pemidanaan tentu saja harus mempertimbangkan humanisme (nilai kemanusiaan). Penerapan pemidanaan harus memberi pemahaman bahwa pemidanaan yang di tetapkan kepada pelaku sesuai dengan

\footnotetext{
2 Ardiani Selvi Dwi. (Tesis). (2003), Kebijakan Pidana Kerja Sosial Dalam Rangka Penuangan Ide Individualisasi Pidana (Studi Terhadap Alternatif Pidana Perampasan Kemerdekaan Jangka Pendek), Semarang: Universitas Negeri Semarang, hlm 72 .

3 Setiady Tolib, (2010), Pokok-Pokok Hukum Penitensier Indonesia, Bandung: Alfabeta. Hlm 21.
}

nilai nilai kemanusiaaan serta sesuai kesalahan yang dilakukan. Pemidanaan yang di jatuhkan oleh hakim dengan sanksi pidana kepada pelaku pelanggaran hukum, bukan sebagai upaya balas dendam.

Sanksi pidana yang berlaku saat ini dan paling banyak dipergunakan dalam peraturan dan perundang undangan adalah sanksi pidana berupa penjara atau kurungan, akibatnya adalah sanksi pidana penjara menjadi favorit untuk dijatuhkan. muncul kecenderungan untuk mencari alternatif pidana penjara. Alternatif pidana penjara bertolak dari kenyataan bahwa pidana penjara semakin banyak dikritik karena pertimbangan kemanusiaan, pertimbangan filosofis, maupun pertimbangan ekonomis. Kritik-kritik terhadap akibat negatif pidana penjara tersebut telah menimbulkan gagasan untuk mencari alternatif selain dari pada pidana penjara walaupun sebenarnya pidana penjara dapat dibenarkan dari sisi pencegahan kejahatan, keamanan masyarakat namun pidana penjara juga memiliki ekses negatif yang cukup besar. ${ }^{4}$

\footnotetext{
4 Tongat, (2001). Pidana Kerja Sosial Dalam Pembaharuan Hukum Pidana Indonesia, Jakarta: Djambatan, hlm 7.
} 
Persoalan pemidanaan bukanlah suatu persoalan yang sepele, menurut Sudarto pemidanaan membutuhkan perhatian yang mendalam dan tindakan yang hati-hati. ${ }^{5}$ Pemidanaan dengan pidana penjara menjadi suatu permasalahan yang serius. Fakta yang terjadi terhadap kondisi lapas yang ada saat ini menimbulkan kritik pada penerapan pidana penjara adalah ketika para pelaku pelanggar hukum dan atau pelaku kejahatan dipidana penjara maka justru angka kejahatan dan tindak pidana tidak pernah menurun dan semakin bertambah. Penjara dianggap sebagai ajang penggemblengan dan pendidikan kejahatan bagi penjahat. Lembaga Pemasyarakatan (selanjutnya disebut Lapas) atau penjara seringkali dijadikan sebagai sekolah bagi para penjahat yang melahirkan penjahat yang lebih professional

Dengan lahirnya para penjahat kambuhan yang pada mulanya melakukan pelanggaran hukum ringan dan dijatuhi pidana penjara justru menjadi penjahat yang lebih profesional, akhirya menambah beban kepada masyarakat karena timbulnya ancaman

\footnotetext{
${ }^{5}$ Sudarto, (1984), Hukum Pidana Dan Perkembangan Masyarakat, Sinar Baru, Bandung: Sinar Baru. hlm 79.
}

yang lebih besar yang ini berarti tujuan pemidanaan yaitu aspek jera tidak terwujudkan bahkan yang terjadi adalah sebaliknya.

Sanksi yang diberikan kepada pelaku juga memberikan efek negatif berupa dehumanisasi yaitu pengasingan dari masyarakat dengan menghilangkan kemerdekaan, hal ini mengakibatkan beberapa dampak negatif dari pidana penjara yaitu seseorang narapidana dapat kehilangan identitas diri akibat peraturan dan tata cara hidup Lapas, selama menjalani masa tahanan apapun kegiatan narapidana selalu dalam pengawasan petugas, sehingga para narapidana merasa kurang aman dan dicurigai atas tindakannya, sangat jelas kemerdekaan individualnya akan terampas, depresi, serta berkumpul dengan para pelaku kejahatan lain justru membuatnya semakin pandai dalam bidang kejahatan.

Selain kurang efektifnya penerapan dalam sanksi pidana penjara, ada aspek negatif dari pidana penjara yang tidak diperkirakan yaitu over capacity. Maklum saja, di Indonesia, semua pelanggaran hukum atau kejahatan hampir selalu berujung pada vonis penjara, tidak peduli kejahatan ringan, pencuri sandal atau koruptor kelas kakap 
sama-sama berujung di penjara. Narapidana harus berdesak-desakan dalam sel yang sempit, layaknya ayam dalam kandang dan melebihi kapasitas ini men-downgrade kemampuan pengawasan dari petugas Lapas untuk mengawasi seluruh aktivitas dari para narapidana. Over capacity ini menjadikan Lapas di Indonesia lebih mirip ‘sekolah kejahatan' di mana para napi justru mendapat pendidikan kejahatan oleh narapidana lainnya. Ketika masuk lapas para narapidana hanya seorang maling ayam, setelah dalam penjara para narapidana 'belajar', dan setelah keluar ia akan menjadi pelaku kejahatan kelas kakap atau perampok. banyak kasus, penjara justru membuat seseorang menjadi lebih banyak teman, lebih jahat atau lebih ahli dalam menjalankan kejahatannya.

Narapidana yang dipidana akibat tindak pidana ringan, dengan masa hukuman yang minimal, serta cenderung suka berbuat onar dalam lapas, ini biasanya juga mempraktekkan ilmu kriminal baru hasil didikan dalam penjara (Suara Karya Online, 2008) Padahal dalam pemidanaan yang bersifat modern, vonis tidak harus berupa penjara. Jika seorang warga negara masuk penjara, maka ia akan menjadi beban negara. Negara harus menyiapkan ruangan dalam penjara, menggaji sipir penjara, menyediakan makanan, minuman dan pakaian, dan fasilitas lainnya yang jumlah nominalnya sangat besar yaitu 2.5 trilyun rupiah untuk tahun 2015. Kemudian timbul pemikiran, bahwa pemidanaan tidak harus berupa vonis penjara, tapi bisa berupa kerja sosial yang jauh lebih bermanfaat. Sedangkan, pidana kerja sosial atau dalam istilah asing sering disebut sebagai community service orders (CSO) adalah bentuk pidana dimana pidana tersebut dijalani oleh terpidana dengan melakukan kerja sosial yang ditentukan ${ }^{6}$.

Pidana Kerja Sosial bagi pelaku tindak pidana ringan dapat memenuhi unsur-unsur pembinaan dan memberikan perlindungan kepada masyarakat. Unsur pembinaan yang berorientasi pada individu pelaku tindak pidana yang dengan pidana kerja sosial terpidana terhindar dari dampak negatif seperti stigmatisasi, kehilangan rasa percaya diri sehingga terpidana memiliki kepercayaan diri yang sangat diperlukan dalam proses integrasi

\footnotetext{
6 Tongat, (2001). Pidana Kerja Sosial Dalam Pembaharuan Hukum Pidana Indonesia, Jakarta: Djambatan. hlm 7.
} 
masyarakat. Kebebasan ini memberi kesempatan kepada terpidana untuk tetap menjalankan kewajiban kepada keluarganya. narapidana juga dapat menghindari dari proses dehumanisasi dan secara otomatis tetap melakukan sosialisasi dengan masyarakat.

Melihat konsep di atas, kerja sosial dalam sistem pemidanaan yang berupa kerja sosial untuk pelaku tindak pidana ringan perlu diterapkan.Pidana kerja sosial yang dijadikan hukuman bagi para pelaku kejahatan misalnya seperti membersihkan toilet umum, membersihkan parit atau selokan, menyapu jalanan, bertugas di panti jompo, dan lain sebagainya. Kerja sosial ini dilakukan secara rutin selama periode hukuman berlangsung. Hakim memvonis sekian bulan untuk menjalani pidana kerja sosial dan negara tidak perlu terbebani harus menghidupi narapidana dan bahkan pidana sosial tersebut bermanfaat untuk kepentingan umum. pidana kerja sosial terpidana tidak akan berusaha untuk belajar kejahatan sebagaimana terjadi apabila berada dalam penjara.

Pemidanaan dengan pidana kerja sosial selama ini belum pernah dikenal dan belum pernah diberlakukan dalam peraturan dan perundang undangan yang ada di Indonesia namun bukan hal yang mustahil untuk diterapkan mengingat beragam benefit dari pidana jenis ini yang benar benar tidak didapatkan dari pemidanaan dengan pidana penjara terutama jika diterapkan bagi pelaku tindak pidana ringan.

Pemidanaan dengan pidana kerja sosial ini walaupun belum dikenal dan belum pernah diberlakukan namun telah berusaha untuk di perkenalkan melalui draf Rancangan Undang-Undang Kitab Undang-Undang Hukum Pidana (RUU KUHP) tahun 2010 yaitu pasal 86 dimana pidana kerja sosial adalah alternatif pidana perampasan kemerdekaan selain pidana penjara dalam jangka pendek. Pidana kerja sosial penting dijadikan salah satu jenis sanksi pidana di Indonesia dengan beberapa alasan yakni lebih bisa memperbaiki terpidana, lebih berguna bagi terpidana dan masyarakat serta lebih memperhatikan hak asasi manusia sebagaimana penjelasan dalam RUU KUHP 2010.

Rumusan masalah

Dari uraian pendahuluan diatas maka dapat diambil rumusan permasalahan sebagaimana yaitu bagaimanakah mengintegrasikan penerapan pidana kerja sosial dalam sistem hukum yang berlaku di Indonesia dan serta seperti apakah efek samping 
bagi pelaksanaan pidana kerja sosial apabila diterapkan di Indonesia.

\section{B. Metode Penelitian}

Penelitian normatif (legal research) dengan pendekatan statute approach dan conceptual approach. $^{7}$

\section{Pembahasan}

Mengintegrasikan Pidana kerja Sosial dalam Sistem Hukum Indonesia

Istilah Integrasi berasal dari bahasa inggris yaitu integration yang berarti pembauran hingga menjadi kesatuan yang utuh dan bulat. ${ }^{8}$ Mengintegrasikan berarti menyempurnakan dengan jalan menyatukan unsur-unsur yang semula terpisah-pisah menjadi sesuatu kesatuan yang utuh sehingga terciptanya keserasian dan keselarasan.

Integrasi dalam hal ini adalah menggabungkan atau mempersatukan pemidanaan dengan pidana kerja sosial kepada sistem hukum positif dan peraturan perundang undangan yang berlaku di Indonesia untuk diberlakukan dan dijadikan alternatif bagi pidana penjara terutama bagi pelaku tindak pidana ringan dimana saat ini pidana kerja

\footnotetext{
7 Peter Mahmud Marzuki, (2008), Penelitian Hukum, Jakarta: Kencana Prenada Media Group., hlm.86-140.

${ }^{8}$ Ali Lukman. (1995), Kamus Besar Bahasa Indonesia. Jakarta: Balai Pustaka, hlm 203.
}

sosial belum menjadi bagian dari sistem hukum di Indonesia sehingga tidak dapat diberlakukan.

Istilah Pidana berasal dari kata belanda yaitu straf atau dapat diartikan sebagai hukuman yang dalam pengertian sempit adalah penderitaan yang dengan sengaja diberikan, ${ }^{9}$ sedangkan menurut Roeslan saleh maka pidana dapat diartikan sebuah reaksi yang terjadi pada delik berwujud sebagai suatu nestapa yang sengaja ditimpakan negara pada delik itu, ${ }^{10}$ Sudarto berpendapat pidana adalah penderitaan yang sengaja dibebankan kepada orang yang melakukan perbuatan yang memenuhi syarat-syarat tertentu. ${ }^{11}$ Syarat-syarat tertentu ini lazimnya disebut dengan unsur-unsur tindak pidana dan seseorang dapat dikenakan pidana apabila perbuatan yang dilakukan memenuhi syarat-syarat tindak pidana yakni semata-mata karena orang tersebut telah melanggar suatu peraturan hukum yang harus ditegakkan oleh negara. ${ }^{12}$

\footnotetext{
9 Hamzah, Andi, (2008), Asas - Asas Hukum Pidana, Jakarta: Rineka Cipt, hlm 27.

${ }^{10}$ Ali Mahrus (Ed.1,Cet.2), (2012), Dasar-Dasar Hukum Pidana, Jakarta: Sinar Grafika, hlm 185.

${ }^{11}$ Ninik Zakiyah, (2016), Hazairin dan Penghapusan Pidana Penjara Pendek, Jurnal Al Ahkam, Volume 26 Nomor 2, hlm 11

12 Lamintang P.A.Fdan Theo Lamintang (Ed. 2, Cet 2), (2012), Hukum Penitensier Indonesia, Jakarta: Sinar Grafika, hlm 33.
} 
Pemidanaan sangat penting untuk dilakukan, mengingat bahwa kegagalan untuk menciptakan rasa injustice karena seorang pelaku tindak pidana mungkin akan memperoleh pidana yang lebih berat dari yang lain, dan sebaliknya. ${ }^{13}$. Badan legislatiflah yang bertugas menerapkan batas pemidanaan (the limit of sentencing), sedangkan pengadilan yang menentukan bobot pemidanaan (the level of sentencing). Ketentuan ini harus adil dan mempertimbangkan pelbagai faktor sehingga terjadi yang dinamakan pemidanaan yang patut (proper sentence).

Sunaryati Hartono berpendapat bahwa suatu sistem hukum nasional adalah terdiri dari Nilai nilai hukum, filsafat hukum, norma-norma hukum, lembaga lembaga hukum, proses dan prosedur hukum, lembaga lembaga pendidikan hukum dan sistem pendidikan hukum, sarana dan prasarana hukum, lembaga lembaga pembangun hukum seperti departemen hukum dan dukungan negara terhadap hukum. ${ }^{14}$

13 Chairul Huda, (2006). Dari Tiada Pidana Tanpa Kesalahan Menuju Kepada Tiada Pertanggung jawaban Pidana Tanpa Kealahan. Tinjauan Kritis Terhadap Teori Pemisahan Tindak Pidana dan Pertanggungjawaban Pidana. Jakarta: Kencana Prenada Media, hlm 125.

${ }^{14}$ Hartono Sunaryati, (2013). Peran State Auxiliary Bodies Dalam Rangka Konsolidasu Konstitusi Menuju Grand Design Sistem Dan Politik Hukum
Sistem hukum nasional menurut Sudikno Mertokusumo adalah suatu tatanan atau kesatuan yang utuh yang terdiri dari bagian bagian atau unsur unsur yang saling berkait erat satu sama lain, Sistem hukum yang hanya berfungsi sepihak maka supremasi hukum tidak dapat berjalan maksimal. ${ }^{15}$

Lawrence M. Friedman mengemukakan bahwa terdapat 3 unsur dari sistem hukum yaitu struktur hukum (structure of law) yaitu pola yang menunjukkan bagaimana hukum dijalankan menurut ketentuan formalnya, dan yang kedua adalah substansi hukum atau (substantion of law) yang merupakan aturan, norma dan perundang undangan yang memiliki kekuatan hukum mengikat. Unsur ketiga adala budaya hukum (legal culture) merupakan hukum yang hidup dalam masyarakat. ${ }^{16}$

Berdasarkan uraian di atas dapat dinyatakan bahwa teori integratif pemidanaan yang merupakan kombinasi dari berbagai teori pemidanaan yang dianggap lebih cocok untuk diterapkan di Indonesia yang tentunya dengan

Nasional. Jakarta: Badan Pembinaan hukum nasional, hlm 33-35.

15 Sudikno Mertokusumo, (2011), Bunga rampai Ilmu Hukum, Jogjakarta: Liberty. hlm 100.

${ }^{16}$ Lawrence M. Friedman, (2002), Sistem Hukum :Perspektif Ilmu Sosial (Terjemahan), Jakarta: Penerbit Nusa Media, hlm 15. 
menggunakan pendekatan sosiologis, idiologis, dan yuridis filosofis, yang dilandasi asumsi dasar bahwa tindak pidana merupakan gangguan terhadap keseimbangan, keselarasan, dan kehidupan masyarakat. Pemidanaan itu sendiri adalah untuk merehabilitasi kerusakan individual dan sosial yang diakibatkan oleh tindak pidana $^{17}$.

Secara etimologis istilah "pidana kerja sosial" berasal dari dua kata yaitu "pidana" dan "kerja sosial". Pidana kerja sosial merupakan bentuk pidana dimana pidana tersebut dijalani oleh terpidana dengan melakukan pekerjaan sosial yang ditentukan $^{18}$ Pidana kerja sosial merupakan jenis pidana yang harus dijalani oleh terpidana di luar lembaga dengan melakukan pekerjaan-pekerjaan sosial, pidana kerja sosial ini tidak dibayar atau dibayar dibawah ketentuan karena sifatnya sebagai pidana (work as a penalty). Jenis pidana kerja sosial ini merupakan pidana yang sebelumnya tidak pernah diatur dalam hukum positif diIndonesia, baik dalam KUHP maupun ketentuan pidana diluar $\mathrm{KUHP}^{19}$.

\footnotetext{
${ }^{17}$ Muladi dan Barda Nawawi Arief. (1992), Bunga rampai Hukum Pidana. Bandung: Alumni, hlm 61.

18 Tongat, Op.Cit. hlm 8.

${ }^{19}$ Ardiani Selvi Dwi, Op.Cit. hlm 69.
}

Pidana kerja sosial adalah jenis pidana pokok yang benar benar baru di Indonesia namun telah dilaksanakan secara meluas dibeberapa negara. Jenis pidana ini adalah merupakan konsekuensidari diterimanya hukum pidana yang "daad dader straafrecht" yang sejauh mungkin mengembangkan alternatif pemidanaan penjara. Bagi terpidana kerja sosial ini dapat dirasakan dapat membebaskan dari hilangnya kemerdekaan.

Keuntungan Pidana kerja sosial menurut Eryna Ganda Nugraha adalah sedikit banyak menisbikan proses stigmaisasi yang selalu mejadi efek samping pidana perampasan kemerdekaan (Penjara). Proses stigmaisasi dalam banyak hal menempatkan seorang terpidana sebagai orang yang distigma sebagai "penjahat" sekalipun orang tersebut telah tidak lagi berbuat kejahatan. Stigmaisasi ini pada gilirannya akan menghambat pembinaan mantan narapidana. Psikologis orang yang telah (terlanjur) "dicap" sebagai penjahat lebih mudah lagi untuk mengulang kejahatan. Logika yang sangat sederhana, daripada hanya sekedar dianggap sebagai penjahat, lebih baik melakukan kejahatan. Tidak berhasilnya pembinaan narapidana karena efek negatif yang berupa "stigmaisasi"ini 
jelas “melahirkan" penjahat residivis. Kegagalan ini pada gilirannya juga harus dibayar mahal oleh masyarakat, karena meningkatknya resiko menjadi korban kejahatan.

Pidana kerja sosial akan menjadikan efek negatif berupa "pendidikan kejahatan oleh penjahat". Sudah menjadi rahasia umum, bahwa Lembaga Pemasyarakatan seringkali berfungsi sebagai "tempat belajarnya para penjahat" yang akan melahirkan penjahat yang lebih professional, ini pada gilirannya juga akan menambah beban kepada masyarakat, karena munculnya ancaman yang lebih besar. Dilihat dari perspektif ekonomi, pidana kerja sosial juga jauh lebih murah dibanding dengan pidana perampasan kemerdekaan. Dengan pidana kerja sosial, maka subsidi untuk biaya hidup narapidana, pembangunan lapas, biaya gaji pegawai dan sipir di lembaga dapat ditekan yang pada akhirnya juga tidak akan membebani masyarakat secara keseluruhan. ${ }^{20}$.

Negara-negara Eropa yang telah menerapkan jenis pidana sosial ini hanya dapat diterapkan dalam jenis tindak pidana

\footnotetext{
${ }^{20}$ Eryna Nugraha Ganda (Tesis), (2003), Kebijakan Legislatif tentang Kebijakan Kerja Sosial, Semarang: Program Pasca Sarjana Undip, hlm 5758.
}

tertentu. Pidana kerja sosial cuma dapat diaplikasikan terhadap tindak pidana yang tidak terlalu berat. Dengan kata lain, pidana kerja sosial tidak dapat dikenakan atau diterapkan terhadap jenis tindak pidana berat. Selain itu pidana kerja sosial juga diterapkan terhadap jenis tindak pidana terhadap harta benda (crimes against property) dengan syarat, bahwa pidana penjara yang akan diterapkan tidak melebihi waktu tertentu (Denmark 6-8 bulan, Norwegia dan Luxemburg 9- 12 bulan, Belanda dan Portugal 4 bulan. ${ }^{21}$

Persyaratan lain yang mungkin ditetapkan berkaitan dengan penerapan pidana kerja sosial adalah persyaratan yang berkaitan dengan si pelaku itu sendiri, misalnya usia pelaku dan criminal record dari pelaku. Penerapan pidana kerja sosial bagi pelaku tindak pidana yang masih dibawah umur juga harus mempertimbangkan adanya peraturan larangan bagi pelaku yang masih di bawah umur yang berdasarkan hukum perburuhan dilarang untuk melakukan kerja. Riwayat sosial juga diperukan untuk menilai apakah secara mental dan fisik terpidana mampu atau siap menjalani kerja sosial (RS, Panti jompo, panti asuhan atau lembaga sosial). Mengingat sifatnya

${ }^{21}$ Tongat, (2001). Op.Cit. hlm 19-20.

Volume 1 No.2 Oktober 2017 ISSN Cetak: 2579-9983 E-ISSN: 2579-6380 Halaman 172-190 
adalah pidana kerja sosial maka tidak boleh mengandung hal hal komersil.

Menurut Luis Manuel Oliviera De Miranda Perereira dalam tulisan berjudul "Community Service in Portugal How Did Community Service Perform Since Its Implementation in 1982 Amandment of The Penal Code" menyatakan "A community service order (CSO) is obviously intended to substitute short detention only. It is upplicable for crimes of which the corresponding penalties do not beyond three months of imprisonment with or without fine”. Pidana kerja Sosial secara jelas dimaksudkan hanya untuk mengganti pidana penjara pendek. Pidana kerja sosial dapat dijatuhkan untuk tindak pidana yang tidak lebih dari 3 bulan dengan atau tanpa denda ${ }^{22}$.

Menurut Konrad Buczowsky dalam bukunya yang berjudul Criminality and criminal justice in contemporary Poland, Sociological perspectives bahwa "Dalam KUHP Polandia maka pidana kerja sosial tidak dimasukkan secara khusus tetapi ada pidana dalam KUHP Polandia yang mirip dengan pidana kerja

22 Luis Manuel Oliviera De Miranda Pereira, (1986), Community Service in Portugal How Did Community Service Perform Since Its Implementation in 1982 Amandment of The Penal Code, Lisbon: UNICRI (United Nations Interregional Crime and Justice Research), hlm 10. sosial yaitu pembatasan kemerdekaan dimana ada kewajiban bagi pelaku tindak pidana untuk bekerja demi kepentingan masyarakat dibawah pengawasan”. ${ }^{23}$

Di Jerman bahwa pidana kerja sosial bisa dipakai sebagai pengganti secara sukarela dari pidana penjara yang harus dihadapi pelaku, jika ia tidak mampu membayar denda. Pidana Kerja Sosial juga dapat berfungsi sebagai persyaratan untuk penangguhan penahanan atau sebagai pidana pokok jika pelaku tindak pidana dengan pengadilan sama sama mensetujui skema tersebut ${ }^{24}$. Pidana kerja sosial pada umumnya tidak akan diterapkan terhadap pelaku kejahatan yang mempunyai catatan kejahatan (criminal record) yang tidak baik atau residivis. Di Perancis misalnya, pidana kerja sosial tidak akan diterapkan terhadap para residivis. Pidana kerja sosial hanya dapat diterapkan terhadap residivis jika ia dengan pidana bersyarat dan bukan sebagai pidana yang tersendiri.

Pengaturan tentang pidana kerja sosial termasuk pula pengaturan tentang

\footnotetext{
${ }^{23}$ Konrad Buzgowsky, (2015), Criminality andcriminal justice in contemporary Poland, Sociological Perspectives, London: Routledge Taylor and Francis Group, hlm. 23.

${ }^{24}$ Anis Masduro Hatun (Tesis), (2003), Ide Pidana Kerja Sosial dan Implementasinya dalam Kebijakan Formulasi Hukum Pidana Untuk Anak Di Indonesia, Semarang: Pasca Sarjana Undip. hlm 31-32.
} 
minimum dan maksimum jam kerja pidana kerja sosial yang di terapkan. Pengaturan jam kerja sosial ini tidak sama di berbagai negara seperti minimum pidana kerja sosial misalnya, terdapat berbagai ketentuan yang berbeda. Di Portugal, pidana kerja sosial secara minimum dilakukan dalam waktu 9 (sembilan) jam per minggu. Sementara di Prancis, Inggris dan Denmark pidana kerja sosial minimum 40 (empat puluh) jam perminggu.

Norwegia memberlakukan pidana kerja sosial dengan minimum 50 (lima puluh) jam perminggu.Berkaitan dengan ketentuan maksimum pidana kerja sosial, ketentuan diberbagai negara juga menunjukkan adanya variasi pengaturan. Di Portugal, misalnya pidana kerja sosial dapat diterapkan dengan maksimum 180 jam. Sementara di Denmark dan Norwegia, maksimum pidana kerja sosial adalah 200 jam. Sedang di Perancis, Belanda dan Inggris pidana kerja sosial dapat diterapkan untuk maksimum 240 jam $^{25}$.

Pidana kerja sosial yang dikemukakan Hazairin sebagaimana

25 BZ Marpiyani (Skripsi), (2013), Perspektif Alternatif Pemberian Pidana Kerja Sosial Bagi Anak Ditinjau Dari Tujuan Pemidanaan, Banjarmasin: Universitas Lambung Mangkur, hlm 32-33. dikutip oleh Ninik Zakiyah merupakan salah satu pidana alternatif bagi pidana penjara dengan waktu singkat (pendek) adalah pidana bekerja untuk kepentingan umum tanpa dibayar. Sistem ini telah dikenal dalam sejarah hukum pidana Eropa sejak beberapa puluh tahun lampau, seperti yang diterapkan di Portugis, Inggris, dan Jerman. Hazairin juga membandingkan hukuman alternatif di berbagai negaranegara lain seperti Belanda dan Luxemburg, terlebih dahulu memperoleh pidana penjara atau pidana denda melalui grasi (ampunan dari kepala negara kepada orang yang mendapat hukuman), untuk kemudian sisa waktu dari penghukuman tersebut diubah menjadi pidana bekerja tanpa dibayar.

Menurut Hazairin alasan setelah ia membandingkan berbagai hukuman sebagai pengganti pidana alternatif dari pidana penjara di Indonesia khususnya, adalah perlunya alternatif pengganti pidana penjara terhadap pelaku tindak pidana, yaitu pidana kerja sosial (socially useful works/community service order). Hal ini didasarkan pemikiran bahwa dalam perspektif penologi, jenis pidana yang dijatuhkan terhadap pelaku kejahatan harus dapat mencapai tujuan pemidanaan, baik dalam konteks prevensi umum maupun prevensi khusus, namun pelaksanaan 
pidana dan tindakan ternyata sistem perawatan yang berperikemanusiaan (misalnya pidana percobaan / probation) sedikit lebih efektif untuk mengurangi kemungkinan pengulangan tindak pidana (residivisme) dibandingkan dengan beberapa bentuk pidana lainnya. ${ }^{26}$

Pemidanaan dengan kerja sosial berdasarkan pada konsepsi individualisasi pemidanaan sebagaimana dirancang dalam RUU KUHP Indonesia. Pidana kerja sosial dapat diterapkan di Indonesia karena secara teoretis, filosofis, empiris dan yuridis dan empiris selaras dengan sila ke lima Pancasila, yaitu Keadilan Sosial bagi Seluruh Rakyat Indonesia, yang didalamnya terkandung nilai keadilan.

Dalam menjalankan pidana kerja sosial, terpidana dituntut bekerja keras selama menjalani masa pemidanaan. Sedangkan secara teoritis pidana kerja sosial sesuai dengan ajaran teori integrasi. Menurut teori integrasi (vernengings theorien), dalam pemidanaan memerlukan adanya pemilahan dan pembedaan antara tahap-tahap pemidanaan narapidana serta berat ringannya tindak pidana karena teori ini mengintegrasikan antara unsur pembalasan dengan unsur tujuan /

\footnotetext{
${ }^{26}$ Ninik Zakiyah, Op.Cit, hlm 10.
}

prevensi $^{27}$. Sehingga dengan pidana kerja sosial ini akan mampu untuk menjadi unsur balasan sekaligus pencegahan agar para terpidana ini tidak semakin jahat setelah masuk penjara.

Dengan persoalan di atas setidaknya Indonesia menerapkan pidana kerja sosial sebagai ganti pidana penjara pendek, dengan ini narapidana dapat terhindar dari stigmaisasi dan prisonisasi, disamping itu narapidana dalam pidana penjara pendek tidak mengikuti pembinaan secara maksimal di lembaga pemasyarakatan dikarenakan singkatnya waktu pemenjaraan. Pidana kerja sosial ini juga tepat jika dijatuhkan kepada penjahat yang pertama kali melakukan kejahatan ${ }^{28}$. Sebagaimana di dunia Internasional maka di Indonesia ini maka juga muncul kecenderungan untuk mencari alternative bagi pidana penjara terutama untuk penjara dalam masa yang pendek. Pidana penjara pendek dirasakan tidak efektif atas pertimbangan filosofis, kemanusiaan maupun ekonomis karena memiliki akibat negatif tidak saja bagi terpidana tapi juga terdakwa.

Diperlukan sebuah politik hukum guna mengintegrasikan pidana kerja sosial

27 Hazairin, (1981), Tujuh Serangkai Tentang Hukum, Bina Aksara, Bandung. hlm 32.

${ }^{28}$ Tongat, Op.Cit, hlm 47. 
kedalam system hukum Indonesia. Sudarto mendefinisikannya sebagai Usaha untuk mewujudkan peraturan-peraturan yang baik sesuai dengan keadaan dan situasi pada suatu saat. Termasuk juga kebijakan dari negara melalui badan-badan yang berwenang untuk menetapkan peraturanperaturan yang dikehendaki yang diperkirakan bisa digunakan untuk mengekspresikan apa yang terkandung dalam masyarakat dan untuk mencapai apa yang dicita-citakan. ${ }^{29}$

Pencegahan dan penanggulangan kejahatan dengan sarana pemidanaan termasuk diantaranya pidana kerja sosial dan mengintegrasikan kedalam system hukum menurut Barda Nawawi Arief fungsionalisasi/opersionalisasi yang dilakukan melalui beberapa tahap yaitu tahap formulasi (kebijakan legislatif), aplikasi (kebijakan yudikatif/yidicial), dan eksekusi (kebijakan eksekutif/ administratif). ${ }^{30}$

Dengan adanya tahap formulasi, maka upaya bukan hanya tugas aparat penegak/ penerap hukum tetapi juga aparat pembuat hukum (aparat legislatif). Selanjutnya dikatakan bahwa kebijakan

\footnotetext{
${ }^{29}$ Sudarto, Op.Cit, hlm 20.

30 Barda Nawawi Arief, (1996), Bunga Rampai Kebijakan Hukum Pidana, Bandung: Citra Aditya Bakti, hlm 77-78.
}

legislatif merupakan tahap paling strategis dari upaya penanggulangan kejahatan karena kesalahan/kelemahan kebijakan legislatif merupakan kesalahan yang dapat menjadi penghambat upaya penanggulangan kejahatan pada tahap aplikasi dan eksekusi.

Dalam bukunya Social Defence, A Modern Approch to criminal problems, Marc Ancel sebagaimana dikutip Barda Nawawi Arief menyatakan bahwa : "Between the study of criminological factors on the one hand, and the legal technique on the others there is room for a science which oberves legislative phenomenon and for a rational art within which scholar and practitioners, criminologist and lawyers can come together, not as antagonist or in fratricidal strife, but as follow workers angaged in a common task, which is first and foremost to bring into effect a realistic, humance, and healthily progressive penal policy" ${ }^{\prime 31}$.

Dengan mengikuti pemikiran bahwa tahap formulasi ialah tahap yang paling strategis untuk penegak/penerap hukum maka seharusnya para sarjana dan praktisi, para ahli kriminologi dan ahli hukum harus berkerja bersama terutama untuk menghasilkan suatu kebijakan

${ }^{31}$ Ibid, hlm 23-24 
pidana yang realistis, humanis, dan berpikiran maju (progresif) lagi sehat berupa pidana kerja sosial. Berdasarkan pendapat Marc Ancel tersebut, dihubungkan dengan tujuan dan makna dari pidana kerja sosial, maka ide atau pemikiran mengenai diwujudkannya serta di integerasikannya sanksi pidana kerja sosial dalam system hukum di Indonesia adalah untuk menghasilkan kebijakan pemidanaan yang sifatnya realistik, humanis dan berpikiran maju (progresif) lagi sehat.

Dengan pemikiran ini, maka peraturan hukum positif yang akan datang (ius constitutum) terutama peraturan mengenai pemidanaan kerja sosial yang dapat dirumuskan secara lebih baik dengan visi sesuai dengan tujuan utama pemidanaan yaitu melindungi masyarakat dan merehabilitasi pelaku kejahatan. Perumusan itu adalah untuk merumuskan secara tepat tentang pidana kerja sosial sehingga dapat berlaku dengan efektif dan mencapai tujuannya secara tepat.

Perumusan itu dengan mempertimbangkan kultur dan kondisi sosiologis dari bangsa Indonesia dan dengan demikian akan menjadi sebuah hukum atau aturan yang benar benar sesuai dengan kenyataan yang ada. Secara formulasi terjadi trasformasi secara konseptual dalam system pidana dan pemidanaan yang mendorong munculnya semangat mencari alternatif yang lebih manusiawi. Pada tataran ini konsep pemidanaan bergeser dari berorientasi kepada pembalasan tetapi berfilosofi kepada pembinaan atau treatment philosophy ${ }^{32}$.

Untuk dapat diintegrasikan di Indonesia maka pidana kerja sosial haruslah dirumuskan oleh pihak yang berwenang sehingga dapat di berlakukan di dalam sistem hukum Indonesia. Integrasi pidana kerja sosial dalam sistem hukum Indonesia berarti diformulasikan dalam peraturan perundang-undangan dan ini termasuk dalam pembaharuan sistem pidana Indonesia dan hal ini termasuk sebagai pembaharuan hukum.

Sebagaimana kita sadari bahwa hukum pidana yang berlaku di Indonesia adalah peninggalan dari kolonial Belanda yang berlaku sejak abad 19 dan secara formal bahwa pemberlakuan hukum pidana Belanda didasarkan pasal II aturan peralihan UUD 1945 namun menjadi pertanyaan tentang efektivitasnya apabila

\footnotetext{
32 Jimly Ash Shidiqie, (1996), Pembenaran Hukum Pidana Indonesia: Studi tentang Bentuk Bentuk Pidana dalam Tradisi Fiqh dan relevansinya bagi Usaha Pembaharuan KUHP Nasional, Bandung: Angkasa,. hlm 61
} 
tidak memenuhi faktor sosiologis dan filosofis bahkan historis ${ }^{33}$ artinya hukum dapat berlaku efektif jika secara yuridis sah. Didukung masyarakat dan sesuai nilai dan cita-cita masyarakat dan menurut Teuku muhammad berpendapat bahwa salah satu syarat keberlakuan hukum dengan baik ialah bahwa hukum tersebut haruslah sesuai dengan aspirasi dan kebutuhan masyarakat. ${ }^{34}$

Apabila dilihat seksama maka hukum pidana di Indonesia jelas tidak dapat memenuhi hal tersebut karena jiwa kolonial jelas berbeda dengan jiwa dan nilai-nilai masyarakat. Diperlukan reorientasi agar pidana kerja sosial, dapat terformulasi dan terintegrasi dalam sistem hukum nasional yang sesuai nilai filosofis , Kultural dan dengan demikian menjadi landasan atas integrasi tersebut. Reformasi tersebut pada hakikatnya mencakup upaya reevaluasi nilai nilai yang melandasi dan memberi isi muatan normatif dan substansif dengan menggali nilai nilai dalam masyarakat agar pidana kerja sosial menjadi serasi dan efektif. Hal ini mendesak untuk dikedepankan mengingat pemidanaan dan hukum pidana dewasa ini

\footnotetext{
${ }^{33}$ Ibid, hlm. 160

34 Teuku Muhammad Radmie, 1983, Peranan Hukum Islam Dalam Pembinaan Hukum Nasional, Bina Aksara, Yogyakarta. hlm 11.
}

tidak menurunkan angka kejahatan dan dibuktikan dengan tingkat overload penjara-lapas diseluruh Indonesia walaupun terus dibangun penjara-lapas baru.

Selain reformulasi juga diperlukan konsptual dan pendekatan yang rasional yang mana pidana kerja sosial itu haruslah sungguh sungguh mencegah dan tidak menyebabkan bahaya lebih merugikan bagi masyarakatdan dengan integrasi itu terwujud kepentingan kepentingan sosial yang mengandung nilai nilai perlindungan warga resosialisai pelanggar hukum tanpa terstigmakan serta mempertahankan integritas martabat dan kemanusiaan individu yang melakukan tindakan pidana pendek atau ringan sebagai pendekatan yang humanistik.

Proses integratif ini perlu sehingga pidana yang dikenakan mampu membangkitkan kesadaran pelanggar akan nilai kemanusiaan dengan kerja sosial dan itu merupakan proses edukatif terhadap pelanggar hukum. Lembaga-lembaga yang terkait perlu pula dipersiapkan terkait teknis, bagaimana kerja sosial yang dimaksud dan bagaimana pengawasannya, registrasinya sehingga akan tepat dan tidak berjalan tanpa terkoordinasi bagaimana usia minimal pelaku dan kriminal, record -nya agar jangan sampai misalnya pelaku 
pembunuhan berantai justru dihukum kerja sosial dan jumlah jam kerja sosial dan hal hal mendetail lainnya perlu di persiapkan dengan seksama.

\section{Kesimpulan}

Pemidanaan tidak harus berupa vonis penjara, sanksi kerja sosial jauh lebih bermanfaat. peraturan hukum positif yang akan datang (ius constitutum) terutama peraturan mengenai pemidanaan kerja sosial dapat dirumuskan secara lebih baik dengan visi sesuai dengan tujuan utama pemidanaan yaitu melindungi masyarakat dan merehabilitasi pelaku kejahatan. Perumusan itu adalah untuk merumuskan secara tepat tentang pidana kerja sosial sehingga dapat berlaku dengan efektif dan mencapai tujuannya secara tepat.

\section{E. Daftar Pustaka}

Ali Lukman. (1995). Kamus Besar Bahasa Indonesia. Jakarta. Balai Pustaka

Ali Mahrus, (2012), (Ed. 1, Cet.2), DasarDasar Hukum Pidana, Jakarta: Sinar Grafika.

Ardiani Selvi Dwi, (2003), (Tesis). Kebijakan Pidana Kerja Sosial
Dalam Rangka Penuangan Ide Individualisasi Pidana (Studi Terhadap Alternatif Pidana Perampasan Kemerdekaan Jangka Pendek), Semarang: Universitas Negeri Semarang

Anis Masduro Hatun, (2003), (Tesis), Ide Pidana Kerja Sosial dan Implementasinya dalam Kebijakan Formulasi Hukum Pidana Untuk Anak Di Indonesia, Semarang: Pasca Sarjana Undip.

Barda Nawawi Arief, (2000), Masalah Penegakan Hukum dan Kebijakan Penanggulangan Kejahatan, Semarang, Universitas Diponegoro.

Barda Nawawi Arief, (1996), Bunga Rampai Kebijakan Hukum Pidana, Bandung: Citra Aditya Bakti.

Bungin Burhan, (2007). Metodologi Penelitian Kualitatif: Aktualisasi Metodologi Ke Arah Ragam Varian Kontemporer, Jakarta : Raja Grafindo Persada.

BZ Marpiyani, (2013), (Skripsi), Perspektif Alternatif Pemberian Pidana Kerja Sosial Bagi Anak Ditinjau Dari Tujuan Pemidanaan, 
Banjarmasin: Universitas Lambung Mangkurat.

Chazawi Adami, (2003), Pelajaran hukum pidana bagian I, Jakarta: Raja Grafindo Persada.

Eryna Nugraha Ganda, (2003), (Tesis), Kebijakan Legislative tentang Kebijakan Kerja Sosial, Semarang: Program Pasca Sarjana Undip.

Andi Hamzah, (2008), Asas - Asas Hukum Pidana, Jakarta: Rineka Cipta.

Hartono Sunaryati, (2013), Peran State Auxiliary Bodies Dalam Rangka Konsolidasu Konstitusi Menuju Grand Design Sistem Dan Politik Hukum Nasional, Jakarta: Badan Pembinaan hukum nasional.

Hazairin, (1981), Tujuh Serangkai Tentang Hukum, Bandung: Bina Aksara.

Huda Chairul, (2006), Dari Tiada Pidana Tanpa Kesalahan Menuju Kepada Tiada Pertanggung jawaban Pidana Tanpa Kealahan. Tinjauan Kritis Terhadap Teori Pemisahan Tindak Pidana dan Pertanggungjawaban Pidana, Jakarta. Kencana Prenada Media.
Ibrahim Jhonny, (2006). Teori dan Metodologi Penelitian Hukum Normatif, Malang: Bayumedia publishing.

Jimly Ashidiqie, (1996), Pembenaran Hukum Pidana Indonesia: Studi tentang Bentuk Bentuk Pidana dalam Tradisi Fiqh dan relevansinya bagi Usaha Pembaharuan KUHP Nasional, Bandung: Angkasa.

Konrad Buzgowsky, (2015), Criminality and criminal justice in contemporary Poland, Sociological Perspectives, London: Routledge Taylor and Francis Group, hlm. 23.

Lamintang P.A.Fdan Theo Lamintang, 2012, Hukum Penitensier Indonesia, Ed. 2, Cet 2, Sinar Grafika, Jakarta

Lawrence M. Friedman, (2002), Sistem Hukum: Perspektif Ilmu Sosial (Terjemahan), Jakarta: Penerbit Nusa Media 
Luis Manuel Oliviera De Miranda Pereira, (1986), Community Service in Portugal How Did Community Service Perform Since Its Implementation in 1982 Amandment of The Penal Code, Lisbon: $\underline{\mathrm{UNICRI}}$ :United Nations Interregional Crime and Justice Research.

Peter Mahmud Marzuki, (2009), Penelitian Hukum, Jakarta: Kencana Prenada Group.

Sudikno Mertokusumo, (2011), Bunga rampai Ilmu Hukum, Jogjakarta: Liberty.

Muladi, (1995). Kapita Selekta Sistem Peradilan Pidana. Semarang : Badan Penerbit Universitas Diponegoro.

Muladi dan Barda Nawawi Arief. (1992), Bunga rampai Hukum Pidana, Bandung: Alumni.

Niniek Suparni, (2007), (Cet.II), Eksistensi Pidana Denda Dalam Sistem Pidana dan Pemidanaan, Jakarta: Sinar Grafika.

Ninik Zakiyah, (2016), Hazairin dan Penghapusan Pidana Penjara
Pendek, Jurnal Al Ahkam, Volume 26 Nomor 2.

Setiono, (2005), Metode Penelitian Hukum, Surakarta: Program Pascasarjana UNS

Setiady Tolib, (2010), Pokok-Pokok Hukum Penitensier Indonesia, Alfabeta, Bandung Syahrani Ridwan, 2004, Rangkuman intisari ilmu hukum edisi revisi, Citra Aditya Bakti, Bandung.

Soerjono Soekanto, (2001), Pengantar Penelitian Hukum, Jakarta: UI Press.

Soekanto Soerjono dan Sri Mamudji, (2009), (Cet.11), Penelitian Hukum Normatif Suatu Tinjauan Singkat, Jakarta: Raja Grafindo Persada

Sudarto, (1984), Hukum Pidana Dan Perkembangan Masyarakat, Bandung: Sinar Baru.

Teuku Muhammad Radmie, (1983), Peranan Hukum Islam Dalam Pembinaan Hukum Nasional, Yogyakarta: Bina Aksara.

Tongat, (2001), Pidana Kerja Sosial Dalam Pembaharuan Hukum 
Pidana Indonesia, Jakarta:

Djambatan.

\section{Media Cetak}

Suara Karya online, Sabtu, 29 November

2008, Lapas Penuh, dihukum satu tahun

tidak usah dipenjara 